\title{
The Death or the Revivals of the Author?
}

\author{
Mohebat Ahmadi \\ English Department, Islamic Azad University, Larestan Branch, Iran \\ Email: mbt_ahmadi@yahoo.com
}

\begin{abstract}
To investigate the relationship between the author and the text, and how different conceptions of that relationship present differing and opposing opinions about how readers should engage with text are the main purposes of this paper. It will be done by comparing Roland Barthes' article, "The Death of the Author", and Michel Foucault's "What is an author?". Foucault and Barthes look at the development of the idea of author and show how it has changed throughout the centuries to go with each period's ideologies. Barthes argues that when the author writes the text, his voice is no more dominant in it. As soon as the writer starts writing, he is dead because when he writes he has no control over the text but it depends on the interpretation of readers. Foucault stops talking about the author and starts talking about the 'author function'. An author's function is based on the narrations that are narrated from him. The name of author indicates a discourse of a special period or it is the symbol of that discourse's signs. What becomes clear is that Foucault sees the authorfunction as one which reveals the coincidence of a complex web of discursive practices.
\end{abstract}

Index Terms — author, reader, discourse, signification, ideology, text

\section{INTRODUCTION}

Historically, the author has been privileged by being viewed as the source of the meaning of a literary work and that the author ought to be the central point of all acts of interpretation. For example, the Romantics had this belief that the poem is the result of the 'spontaneous overflow of the powerful feeling' of the poet. More recently, the auth or has been removed from his privileged position resulting in views such as Barthes's that the author is only the effect rather than the cause of the text. Foucault examines the 'author' as a concept made up by the various discourses since it hasn't been before coming of a text. Sean Burke in his book, The Death and Return of the Author: Criticism and Subjectivity in Barthes, Foucault and Derrida, refers to this new postmodern plan offered by Barthes and Foucault:

Man can no longer be conceived as the subject of his works, for to be the subject of a text or of knowledge is to assume a post ideally exterior to language. There can thus be no such thing as subjectivity whilst the subject or author as has classically been the case - is conceived as prior to a language which exists as an entirely transparent vehicle or medium for his uses - his designs. (1998, p. 15)

It is the same conclusion that Foucault and Barthes referred to in their named essays. For them, the concept of the "author" and his intention for the work should not be used to limit readers' interpretations of text. The author's self serves less to link a text to the person writing it or the real person outside who produced it. The complexity of the narrative voice in the fictional world of a text can only be understood by the readers who continuously make conformities between the idea of author and the ideology of their age: "Barthes and Foucault ask what shall fill the empty space left by the death or disappearance of the author? Their answer, the reader" (Irwin, 2002, p. xiii).

\section{RONALD BARTHES AND THE DEATH OF THE AUTHOR}

Ronald Barthes in his article, "Authors and Writers" claims that "the author is the only man, by definition, to lose his own structure and that of the world in the structure of language" hence, it can never explain the world" (1982, p. 187). It seems that the author has no relation with his text and the text will be separated from his creator. Similarly, at the beginning of "The Death of the Author", written in 1967 and published in 1968, after quoting a sentence from Balzac's Sarrasine, Barthes challenges the role of the author by inquiring:

Who is speaking thus? Is it the hero of the story bent on remaining ignorant of the castrato hidden beneath the woman? Is it Balzac the individual, furnished by his personal experience with a philosophy of Woman? Is it Balzac the author, professing certain "literary" ideas on femininity? Is it universal wisdom? Romantic psychology? We shall never know, for the good reason that writing is the destruction of every voice, of every point of origin. Writing is that neuter, composite, oblique space where our subject slips away, the negative where all identity is lost, starting with the very identity of the body writing (p. 221).

Barthes argues that a text becomes a text when it is put into writing; it is a text, purely because it comes into existence, not because it is created by an author but it is the language which gives it sound and meaning. The meaning that is behind Barthes' assertion is that: "It is language which speaks, not the author". At the time the author finishes his task, the text changes into "a sacred merchandise, produced, taught, consumed, and exported in the context of a sublime economy of values" (1982, p. 189). A text has no respect and its respect can be easily broken. The author is the text's guest whose being does not precede writing but in contrast is constituted and confined by writing itself. The 
author, as Barthes says, changes into a "paper I"; he isn't a complete "I" rather has an intertextual relationship with the text and so everybody can interpret the author in one way.

According to Barthes, text is like a piece of music that demands the reader's participation. A text wants you as a reader to play it and reproduce it as the same as musical keys that must be played to produce sounds. The author cannot decode all the secrets of a text. Then, the death of the author can be conveyed as the birth of the reader. It seems that the existence of a text is separated from its author. When an author writes, he writes as an end in itself, thus paying respects to a literary institution which bases its power on language. A text can be read without its author or father. Derrida says what you write is because you know that you aren't, and if you were sure that you remain present always, you wouldn't write. Then, both writing and speaking are based on the idea of absence. In other words, text is a dynamic system that can be identified by its own changeable layers of signs.

\section{Michel FouCAUlT AND 'WHAT IS AN AUTHOR?' God and man died a common death. (Foucault, 1977, p. 121)}

Whilst Barthes denies the individuality of the author as merely an obstacle to be excluded, Foucault opens the way to a new understanding of the meaning of the authorship. Foucault points out that the author is anything but 'dead' in that it (rather than he or she) is a concept constituted over time. Foucault believes that a text refers to an author and does not refuse the author entirely. Unlike Barthes, Foucault doesn't kill the author but he changes the author into a function that plays a role and after performing his role he follows another function. Then, while Foucault's conclusions agree with the statement that "It is language which speaks, not the author", he does not go so far as to say that the author, because of this, does not exist. He doesn't want his readers to assume that authorship is a "dead issue," a problem that's already been solved by Barthes. He accepts that literature must have an author and creator, just as it must have a reader. Foucault reminds us that although we regard the concept of authorship as "solid and fundamental," that concept hasn't always existed. It "came into being," Foucault explains, at a particular moment in history, and it may be fainted at some future moment.

Michel Foucault attempts to revise some of the more recent conceptions of authorship in critical theory. Foucault begins his article "What is an author?" in 1969 with this Beckett's famous statement that "What does it matter who is speaking, someone said, what does it matter who is speaking". Foucault says that the "task of criticism is not to reestablish the ties between an author and his work or to reconstitute an author's thought and experience through his works" (1977, p. 118). Under the influence of poststructuralism, the principle sense of contemporary opposition to the idea of the author is that writing does not derive from the "exalted emotions related to the act of composition or the insertion of the subject into language" (p. 116). The text is viewed today, rather, as an "opening where the writing subject endlessly disappears" (p. 116) precisely because all writing is viewed as an "interplay of signs, regulated less by the content it signifies than by the very nature of the signifier" (p. 116). In other words, the 'author' can be replaced by the most basic Derridean terms such as 'differance' and 'writing'. Foucault eliminates the author as a centre that has its function in directing it. One can see a clear similarity between the functional role of Derridean Centre and Foucauldian author in this extract by Derrida:

Thus it has always been thought that the centre, which is by definition unique, constituted that very thing within a structure which while governing the structure, escapes structurality. This is why classical thought concerning structure could say that the centre is, paradoxically, within the structure and outside it. The centre is at the centre of the totality, and yet, since the centre does not belong to the totality (is not part of the totality), the totality has its centre elsewhere. The centre is not the centre. (Derrida, 1978, p. 352)

Instead of being in control of their texts, the authors have shifted their traditional stable position into the temporary products of their own writings. Then, it is the text or, in other words, the language itself that puts an end to its author who is "a victim of his own writing" (Foucault, 1977, p. 117) because the text has lost its own final structure through the play of language and "where a work had the duty of creating immortality, it now attains the right to kill, to become the murder of the author" (p. 117). In contemporary culture, writing is associated with death insofar as a text orders the execution of the author.

To reexamine the author's disappearance, Foucault refers to several functions of the author. Firstly, an author's name is more than a mere label and reference to or a description of a particular individual in that it is linked less to an individual than to his achievements. An author's name performs different roles. Foucault asks us to think about the ways in which an author's name "functions" in our society. Whether an author is dead or not, one must see his name on the work. The author's name is not a proper noun but it is a general one because it has no special and unique reference:

We can conclude that, unlike a proper name, which moves from the interior of a discourse to the real person outside who produced it, the name of the author remains at the contours of texts - separating one from the other, defining their form, and characterizing their mode of existence. (p. 123)

Then, Foucault restricts his original question of 'What is the name of an author?' to 'How does it function?'. The name of the author no longer describes what it names; instead, it is to be characterized by its function, in the sense of its discursive effects. The "author function" is more like a set of principles governing the classification and consumption of texts. It is like you want to know the problem of deciding whether or not a given text should be attributed to a particular author. What would happen if we attribute an unknown text to a well-known writer like James Joyce? He argues that the author exists as the creator of a work but it is language which defines a text; an author is simply a name, not a code of 
meanings. Not only the author's name is an element in the discourse, but it is itself a kind of discourse and can define a kind of discourse or introduce a special definition of a discourse. A single text can contain different authors or multiple 'I' from an author. However, readers always want a single text with an author and want to lead a text to singularity and the legal 'I' of a text. Foucault believes that an author must not refer to a single and true person and each book can have more than one author. The concept of the 'author' may refer to the author of a whole school or a discipline; such as what we know as the Aristotelian, Freudian and Shakespearean school of thought. They can change into cultural products by taking different titles. In this way, the author is not "just the author" of major works but "they have established an endless possibility of discourse" (1977, p. 114) or he is what Foucault calls a "transdiscursive position". Freud can be the founder of different discourses and even the writings that he did not write. It is because of the fact that he makes possible the existence of other texts. For example, it was because of Freud that Hitchcock could make his famous work 'Vertigo'. These writers can leave the signs of their own traces forever. In other words, they are the beginners and founders of discourses.

Secondly, an author's name "serves as a means of classification" (p. 123). The author's name groups together a number of texts and the author function takes the control of a group of texts or discourses under one name, and offers instructions on how the text should be read. In this sense, the author function goes beyond the level of simple indication; rather, it is a framework that puts in itself a discursive unity. By attaching a number of texts to a single name, "relationships of homogeneity, filiation, reciprocal explanation, authentification" (p. 123) are established among them. The subject no longer seems to have full power when it comes to interacting with a text. The "author function" appears to anticipate the subject's reactions.

Thirdly, an author's name also indicates a "particular manner of existence of discourse" (p. 123) because its "status and its manner of reception are regulated by the culture in which it circulates" (p. 123). It points to the existence of certain groups of discourse and refers to the status of this discourse within a society and culture. In short, the "name of an author is a variable that accompanies only certain texts to the exclusion of others" (p. 124). Thus, the function of an author is not to apply only to individual works but also to larger discourses or, in Foucault's words, it "characterize the existence, circulation, and operation of certain discourses within a society" (p. 124).

There are some main distinguishing characteristics of discourse attributed to an author because it is discourse that guarantee the credibility of different readings have been made of a text rather than its authorship. We construct the 'author' by appointing to a set of psychological characteristics. These qualities have little to do with the real individual who wrote the texts:

It results from a complex operation whose purpose is to construct the rational entity we call an author. Undoubtedly, this construction is assigned a 'realistic' dimension as we speak of an individual's 'profundity' or 'creative' power, his intentions or the original inspiration manifested in writing. Nevertheless, these aspects of an individual, which we designate as an author (or which comprise an individual as an author) are projections, in terms always more or less psychological, of our way of handling texts: in the comparisons we make, the traits we extract as pertinent, the continuities we assign, or the exclusions we practise. (p. 127)

Thus 'texts' have now been described as defenseless pieces of writing, to which we attack with those interpretive procedures which construct the author-function. Of course, Foucault continues that: "all these operations vary according to the period and the form of discourse concerned. A 'philosopher' and a 'poet' are not constructed in the same manner [...]" (p. 127). these operations vary according to the form of discourse and the period in question. For example, poets are not constructed in the same manner and, even within the same genre of discourse, there is a huge difference between the reading of classical and modern novelists. A text is not limited to a specific time or place; instead, it is spread in time and place and so it is better to name it as a 'social text'. However, author is not a source of infinite meaning but rather part of a larger system of beliefs that try to limit meaning. Foucault argues that there is a disjuncture in all such texts between the actual writer and the fictional narrator/persona: it is "as false to seek the author in relation to the actual writer as to the fictional author" (p. 129). It seems that personal pronouns act in a complicated way and refer to a "second self" that has no definite identity with the author. The construction of author does not refer to one self; it is also a complex grammatical operation that can give rise to many selves. When a novel is narrated in first person, the "I" refers neither to the author nor to the character; it really refers to a space in between that society has labeled "author" but could be labeled differently. All discourse to which an author is attributed is not characterized by "an actual individual in so far as it simultaneously gives rise to a variety of egos and to a series of subjective positions that individuals of any class may come to occupy" (p. 130). The author himself is a character; a work of fiction, who, in the process of writing, plays various authorial roles and adopts certain personas and emotions: "Everyone knows that, in a novel narrated in the first person, neither the first person pronoun, nor the present indicative refer exactly either to the writer or the moment in which he writes".

\section{Conclusion: Resolving the Author With the TeXT}

The ideological production of a society determines the author function limitation on the ways a text can be read and so readers and critics' interpretation can be restricted through appealing to "authorial intention". However, it can change over time. Paradoxically, Foucault sees the concept of author as an ideological production as a means of exciting new meanings to readers but it is not a kind of complete freedom and it shows itself as a suppression of infinite 
interpretations or as "thrift in the proliferation of meaning" (Foucault, 1977, p. 137). This point is reminiscent of Derrida's paradoxical position towards metaphysical system of thought. He argues that on the one hand, always we are faced with a chain of signification or substitution of signifieds with signifiers that defers our access to a definite signified. On the other hand, there is no escape from metaphysics of presence because removing any limit for the play of signification and rejecting any final transcendental signified has another consequence and it is the rejection of "the concept and the word 'sign' itself", but Derrida adds that it is something "which is precisely what cannot be done" (Derrida, 1978, p. 354). Then, there must and will always be some restriction working upon us. Though Foucault expects an author to be lost in his text, he also will be expected to step outside of his writing and take responsibility for it. To put it another way, the 'author-function' differently acts as both cause and effect, as emerging from the text and as imposed upon it. This contradictory view can be clearer when Foucault refers to the independency of scientific texts on established methods and truths and not its writer and, by contrast, literary text's dependency on its author to maintain its survival.

Foucault thinks of the subject or the authors, not as 'dead' but as very much alive, who "produced not only their own work, but the possibility and the rules of formation of other texts" (Foucault, 1977, p. 131). "What is an author?" indicates that an author cannot be treated as a person and so it is not possible to die. In fact, there is nothing to die, it has been made and as Burke says: "the principle of the author most powerfully reasserts itself when it is thought absent" or "the concept of the author is never more alive than when thought dead" (1998, pp. 6-7). While Barthes thinks of an author coming before the writing of a text, Foucault asserts that we make an author repeatedly after the writing of a text based on our own discourses. Author's role is not to "restore the theme of an originating subject, but to seize its functions, its interventions in discourse, and its dependencies" (p. 137). Then, based on this description of an author, a discourse is dependent on its initiator and so returning to it continuously and recovering the author function that always stands as the central point of reference: "A text has an inaugurative value because it is the work of a particular author, and our returns are conditioned by this knowledge" (p. 136). Foucault encourages a departure from the common old questions such as "how does a free subject penetrate the density of things and endow them with meaning; how does it accomplish its design by animating the rules of discourse from within?" (p. 138) and "Who is the real author?" (p. 138). Instead, he wants us to ask: "under what conditions and through what forms can an entity like the subject appear in the order of discourse; what position does it occupy; what functions does it exhibit; and what rules does it follow in each type of discourse. (p. 138) and "what are the modes of existence of this discourse?"(p. 138). "Where does it come from; how is it circulated; who controls it?" (p. 138).

\section{REFERENCES}

[1] Allen, Graham. (2003). Roland Barthes. New York and London: Routledge.

[2] Barthes, Roland. (1982). Authors and Writers. In Susan Sontag (ed.), A Barthes Reader. New York: Hill and Wang, 185-193.

[3] Barthes, Ronald \& Kartine Pilcher Keuneman (eds. \& trans.) (2007). Criticism and Truth. Kartine Pilcher Keuneman.. New York: Continuum International Publishing Group.

[4] Barthes, Ronald. (2002). The Death of the Author. In Alistair McCleery \& David Finkelstein (eds.), The Book History Reader. New York: Routledge, 221-224.

[5] Birns, Nicholas. (2010). Theory after Theory: An Intellectual History of Literary Theory from 1950 to the Early 21 st Century. Toronto: Broadview Press.

[6] Burke, Sean. (1998). The Death and Return of the Author: Criticism and Subjectivity in Barthes, Foucault and Derrida. Edinburgh: Edinburgh University Press.

[7] David A. Gerstner \& Janet Staiger (eds.). (2003). Authorship and Film. London: Routledge.

[8] Derrida, Jacques. (1978). Writing and Difference. Alan Bass. (trans.). London: Routledge.

[9] Foucault, Michel. (1970). The Order of Things: An Archaeology of the Human Sciences. New York: Vintage Books.

[10] Foucault, Michel. (1977). What is an Author?. In Donald F. Bouchard. (ed.). D. F. Bouchard \& Sherry Simon. (trans.), Language, Counter-Memory, Practice. New York: Cornell University Press, 113-38.

[11] Gallop, Jane. (2011). The Deaths of the Author: Reading and Writing in Time. New York Duke University Press.

[12] Glass, Loren Daniel. (2004). Authors Inc: Literary Celebrity in the Modern United States, 1880-1980. New York: New York University Press.

[13] Irwin, William. (2002). The Death and Resurrection of the Author?. New York: Greenwood Press.

[14] Smart, Barry. (2002). Michel Foucault. New York and London: Routledge.

[15] Weber, Myles. (2005). Consuming Silences: How We Read Authors Who Don't Publish. New York: University of Georgia Press.

Mohebat Ahmadi holds MA and BA in English language and literature and has been the faculty member of Islamic Azad University of Larestan, Iran for the past five years. She is now a PhD candidate at the University of Melbourne, Australia. Her main interests of research are theatrical studies, ecocriticism and poststructuralism. She has joined two professional organizations: ASLEUKI and EASLCE since 2010 and participated in some international conferences. Her latest publications are: Environment, Language, and Organic Imagination: The Case of William Wordsworth, Samuel Beckett and Edward Bond in European Journal of Social Sciences, Vol.30, No.3 (2012), pp. 451-460 and A Deconstructive Reading of Samuel Beckett's The Unnamable: The Threshold of Language Limits in CSCanada: Studies in Literature and Language, Vol. 5, No. 1, 2012, pp. 1-9. 